\title{
Effect of Range Condition on Density and Biomass of Nematodes in a Mixed Prairie Ecosystem
}

\author{
J.D. SMOLIK AND J.K. LEWIS
}

\begin{abstract}
Nematode density and biomass were determined by taxa from exclosures in excellent or fair range condition in western South Dakota. Density of plant feeding nematodes in both treatments varied from 2 to 6 million/ $\mathrm{m}^{2}$ to a depth of $60 \mathrm{~cm}$. Biomass of plant feeders was greater in the excellent condition range due principally to high numbers of dagger nematodes (primarily Xiphinema americanum). The main contributors to biomass estimates in fair range condition were Tylenchida, principally stunt and spiral nematodes. Biomass of predaceous forms was similar to that of plant feeders. Microbial feeders, although numerous, constituted a relatively small proportion of biomass in both treatments. Approximately $70 \%$ of nematodes in all trophic levels occurred above $20-\mathrm{cm}$ sampling depth in both range conditions. Stunt nematodes were nearly limited to the upper $10 \mathrm{~cm}$ of soil, with spiral nematodes predominating with increasing depth, particularly in fair condition range. Results indicate that nematode constitute a major portion of the faunistic biomass in a mixed prairie ecosystem.
\end{abstract}

The role of soil-inhabiting nematode in native grasslands of the Great Plains states has received little investigation. Studies by Orr and Dickerson (1967), Thorne and Malek (1968), Schmitt and Norton (1972), Thorne (1974), and Norton and Schmitt (1978) have established the fact that plant parasitic nematodes are important components of these grasslands. In western South Dakota nematicide treatments resulted in growth increases ranging from 28 to $59 \%$ in native range (Smolik 1977). There is also evidence from New Zealand that nematodes may be limiting pasture production (Yeates 1977). Plant-feeding nematodes in other grassland ecosystems have been investigated by Yuen (1966), Wasilewska (1974), Yeates (1974), Smolik and Rogers (1976), and Freckman et al. (1979).

The objectives of this study we re to determine the effects of range condition and depth of sampling on nematode density and biomass over a 6-year study period. Further analyses are planned to investigate the effects of other abiotic factors on nematode populations.

\section{Materials and Methods}

This study was conducted at the Cottonwood Range and Livestock Exp. Sta., 12 miles west of Philip, S. Dak. This area was on the Comprehensive Network site of the Grassland Biome Project, U.S. International Biological Program as described by Lewis (1970). Samples were taken in a permanent exclosure in excellent range condition (Soil Conserv. Serv. 1969) and in a temporary exclosure in fair range condition. Soils were Kyle silty clays on gentle northeasterly slopes and are included in the Clayey Range

\footnotetext{
Authors are associate professors, Plant Science and Animal Science Departments, respectively, South Dakota State University, Brookings 57007. This report is Contribution No. 1750. Journal Series, South Dakota Agr. Exp. Sta.

The late Professor Gerald Thome provided considerable assistance during the initial phases of this study.

iScientific names of grasses follow Hitchcock and Chase (1951) and common names follow Beetle (1970).
}

Site, Western South Dakota Guide Area, land Resource Area 60-5. Vegetation in excellent range condition was dominated by the cool-season midgrass Agropyron smithiil (western wheatgrass) with an understory of the warm-season shortgrasses Buchloe dactyloides (buffalograss) and Bouteloua gracilis (blue grama). In fair range condition the vegetation was dominated by the two shortgrasses.

Soil cores were obtained on three dates in 1970, 1971, and 1972. Generally, sampling dates coincided with initiation of growth in spring, peak standing crop of live plus recent dead vegetation (late July), and late fall just prior to frost. Samples were obtained for 3 additional years (1973, 1974 and 1975) in July only. Soil cores, 4.2 $\mathrm{cm}$ diameter, were removed to a depth of $60 \mathrm{~cm}$, subdivided into $0-10,10-20,20-30,30-40,40-50$, and $50-60 \mathrm{~cm}$ depth increments, placed in plastic bags and stored at $4^{\circ} \mathrm{C}$ until processed. Six randomly selected cores were removed from both treatments on each date.

Nematodes were extracted from samples by the method of Christie and Perry (1951). In an attempt to estimate the actual populations, nematode numbers were corrected for extraction efficiency. The efficiency of the wet screening, using a 325-mesh screen, was approximately $73 \%$. The extraction efficiency did not vary appreciably between small forms (pin nematode) and larger forms (dorylaims). The efficiency of the Baermann funnels was influenced by ambient extraction room temperatures and this efficiency varied with sampling dates and ranged from 70 to $90 \%$. Efficiency of this portion of the method was determined by carefully examining approximately $10 \%$ of the residues at each extraction date. Dorylaims remained in screen residues more frequently than other taxa and consequently their numbers were corrected independently.

Nematode densities were determined by counting the number present in each of three $1-\mathrm{ml}$ aliquants of a $50 \mathrm{ml}$ suspension in Scott hookworm larvae counting slides at $60 \times$ magnification. Specific identification and values for biomass determination (Andrassy 1956) were obtained from permanent mounts (Thorne 1961) of individuals selected at random from samples combined by date, treatment and depth. Biomass was calculated by multiplying the average weight per individual (Table 1) times the number of individuals per $\mathrm{m}^{2}$. In total, approximately 1,000 mounts containing from 2 to 12 nematodes per slide were prepared. Lyophilization was used to determine a moisture content in nematodes of 75\%. Trophic levels were based on published reports (Thorne and Swanger 1936, Thorne 1939, Goodey 1951, Hollis 1957, Ferris 1967, Nielson 1967, Tjepkema et al. 1971, and Ferris 1972). In addition, the only stylet-bearing nematode indigenous to the Cottonwood site that successfully colonized a fungal substrate was Aphelenchus sp. (authors unpublished)

Nematodes were divided into 9 taxonomic groupings when counted. The nematode genera and/or species, common name, trophic level, weight, and composition of each taxonomic group- 
Table 1. Taxonomic groupings used in comparisons of nematode number, biomass, and trophic level data obtained at the Cottonwood site.

\begin{tabular}{lllll}
\hline \hline Taxonomic grouping & Common name & Trophic level & Weight & Genera and/or species within taxonomic grouping \\
\hline Tylenchorhynchidat & Stunt & Plant feeding & $0.0860^{1}$ & $\begin{array}{l}\text { Tylenchorhynchus robustoides (90)2; T. nudus (6); } \\
\text { T. maximus (2); Quinisulcius acutus (1); Trophurus } \\
\text { minnesotensis (1). }\end{array}$ \\
& & &
\end{tabular}

$\begin{array}{llll}\begin{array}{l}\text { Helicotylenchus } \\ \text { Longidoridae }\end{array} & \text { Spiral } & \text { Plant feeding } & 0.1126 \\ \text { Dagger } & \text { Plant feeding } & 0.6498 \\ \text { Paratylenchus } & \text { Pin } & \text { Plant feeding } & 0.0131 \\ \text { Tylenchidae } & & \text { Plant feeding } & 0.0294\end{array}$

Helicotylenchus leiocephalus (87); H. glissus (12).

$\begin{array}{lllll}\text { Helicotylenchus } & \text { Spiral } & \text { Plant feeding } & 0.1126 & \text { Helicotylenchus leiocephalus (87); H. glissus (12). } \\ \text { Longidoridae } & \text { Dagger } & \text { Plant feeding } & 0.6498 & \begin{array}{l}\text { Xiphinema americanum (97); X. vuittenezi(2); Long- } \\ \text { idorus crassus (1). }\end{array}\end{array}$

Tylenchidae

Plant feeding

Paratylenchus vexans (64); P. brevihastatus (33); $P$. pesticus (2).

Tylenchus exiguus (49); $T$. parvissimus (24); $T$. plattensis (1); Ditylenchus caudatus (6); D. microdens (2); Basiroides conurus (13); Basiria graminophila (2); Psilenchus elegans (2); P. hilarulus (1);

$\begin{array}{llll}\begin{array}{l}\text { Pratylenchus } \\ \text { Dorylaimida }\end{array} & \text { Lesion } & \text { Plant feeding } & 0.0271 \\ & \text { Dorylaims } & \text { Plant feeding (40) } & 0.3219 \\ \text { Dorylaimida } & \text { Dorylaims } & \text { Predaceous (60) } & 0.9143 \\ & & & \\ \text { Mononchus } & & \text { Predaceous } & 1.0388 \\ \text { Rhabditida } & & \text { Microbial feeding } & 0.0795\end{array}$

Pratylenchus tenuis (85); $P$. scribneri (15).

Pungentus (23); Dorylaimellus (19); Tylencholaimellus (19); Axonchium (16); Belondira (10); Dorylaimoides (6); Tylencholaimus (4); Leptonchus (2). Eudorylaimus (45); Aporcelaimellus (41); Nyyolaimus (10); Akrotonus (1); Mesodorylaimus (1); Laimydorus (1); Solidens (1); Discolaimium (1).

Rhabditida

Microbial feeding $\mathbf{0 . 0 7 9 5}$

Mononchus papillatus (80); Tripyla arenicola (20).

Acrobeles (39); Cephalobus (27); Chiloplacus (15); Eucephalobus (10); Plectus (3); Cervidellus (3); Acrobeloides (2); Aphelenchus (2); Wilsonema (1).

'Average dry weight $(\mu \mathrm{g})$ of an adult nematode.

${ }^{2}$ Figure in parenthesis indicates the percentage composition of each grouping based on occurrences in permanent mounts of randomly selected individuals.

ing are shown in Table 1. The number of cyst nematode larvae cxtracted from samples and the number of endoparasites (lesion nematodes) recovered through root incubation (Thorne 1961) were consistently low throughout the study period and are not included in totals.

\section{Results and Discussion}

Range condition did not appear to influence the number of different species present (Fig. 1). However, the $0-10 \mathrm{~cm}$ samples had more than twice the number of species than samples from the $20-60 \mathrm{~cm}$ depths. The number of species of plant feeders remained comparatively high through all sampling depths (Fig. 1); however, the number of species of both predators and microbial feeders was relatively high in only the $0-10 \mathrm{~cm}$ depth. This greater number apparently reflects the greater variety of food sources available in the upper soil layers.

Summaries of significance in the analyses of variance of density and biomass for various dates, 1970-1972 and for July only, 1970-1975 are shown in Tables 2 and 3, respectively. Range condi-

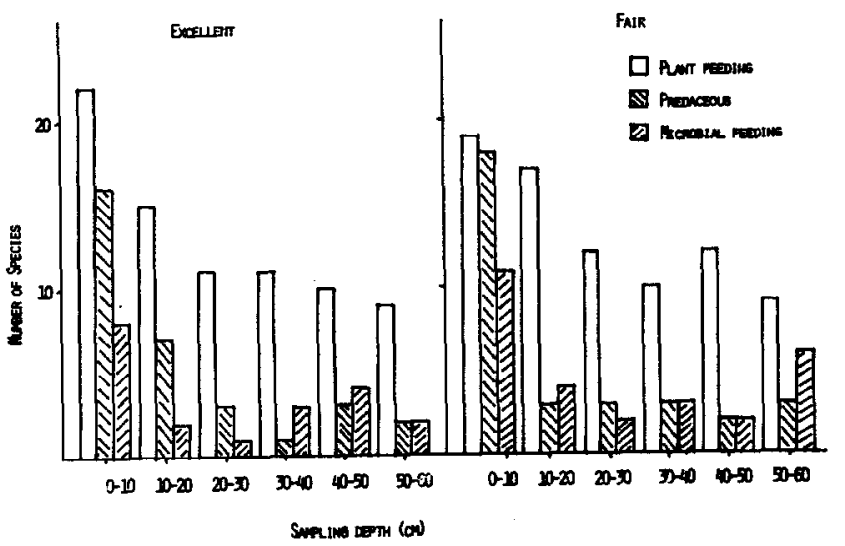

Fig. 1. Number of plant feeding, predaceous and microbial feeding nematode species in excellent and fair condition range. tion as a main effect was seldom significant; however, condition by increment and in some instances condition by increment by year or date interactions were significant $(P<.05)$. Consequently, significant interactions were graphed and FLSD's at .05 (Carmer and Swanson 1971) were used to compare treatment means.

The biomass of plant feeders was significantly greater in excellent condition range only in the $10-20 \mathrm{~cm}$ depth increment on all sampling dates in 1970 and in October of 1971 (Fig. 2). In 1972 biomass was significantly greater in the $0-10$ and $20-30 \mathrm{~cm}$ increments in March and in the $0-40 \mathrm{~cm}$ increments in July (Fig. 2). When July samplings from 1970-1975 are compared (Fig. 3) the biomass of plant feeders was significantly greater in at least one depth increment in excellent range in every year except 1971.

The vertical distribution of plant feeders for all dates, 1970-1972 and for July is shown in Figure 4. Reasons for the highly significant increment effects in the analyses of variance (Tables 2 and 3 ) are apparent since the majority of namatodes occurred in the $0-20 \mathrm{~cm}$ soil increments, as might be expected (Wallace 1963). In contrast to

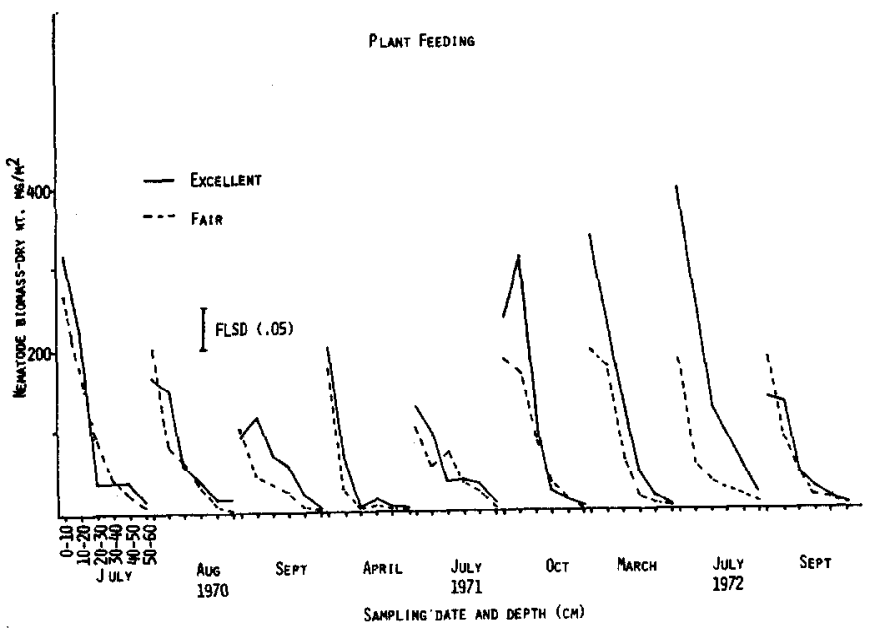

Fig. 2. Effect of range condition on biomass of plant feeding nematodes, 1970-1972. 
Table 2. Summary of significance in analyses of variance of nematode density and biomass data, 1970-1972.

\begin{tabular}{|c|c|c|c|c|c|c|c|c|c|c|c|c|}
\hline Source: & $\begin{array}{c}\text { Plant } \\
\text { feeding }\end{array}$ & $\begin{array}{c}\text { Biomass, } \\
\text { Plant } \\
\text { feeding }\end{array}$ & Stunt & Spiral & Pin & $\begin{array}{l}\text { Tylen- } \\
\text { chidae }\end{array}$ & Dagger & Lesion & $\begin{array}{l}\text { Dorylaims } \\
\text { (Plant } \\
\text { feeding- } \\
\text { excl. } \\
\text { dagger) }\end{array}$ & $\begin{array}{l}\text { Preda- } \\
\text { ceous }\end{array}$ & $\begin{array}{c}\text { Microbial } \\
\text { feeding }\end{array}$ & $\begin{array}{c}\text { Biomass, } \\
\text { Pread- } \\
\text { ceous }\end{array}$ \\
\hline & \multicolumn{12}{|c|}{ Probability of $F$} \\
\hline Condition & - & * & - & - & $* *$ & - & ** & * & - & - & - & 一 \\
\hline Year & $* * 1$ & ** & - & * & - & - & $* *$ & ** & $*$ & $*$ & - & $*$ \\
\hline Yr. $\times$ Cond. & ** & $*$ & - & - & - & - & $*$ & $* *$ & - & - & - & - \\
\hline Dates (yr.) & ** & *** & - & - & $* *$ & $* *$ & $* * *$ & - & $* * *$ & $* * *$ & $*$ & $* * *$ \\
\hline Cond. $X$ dates $(y r)$. & - & $*$ & - & - & - & - & $* *$ & - & - & - & - & 一 \\
\hline Increments & $* * *$ & $* * *$ & $* * *$ & $* * *$ & $* * *$ & $* * *$ & *** & $* * *$ & $* * *$ & $* * *$ & $* * *$ & $* * *$ \\
\hline Cond. $X$ incr. & $* * *$ & $* * *$ & $* * *$ & **** & $*$ & * & $* * *$ & $* * *$ & $*$ & ** & $* *$ & $* *$ \\
\hline Yr. $X$ incr. & - & ** & - & - & - & - & $* * *$ & $* * *$ & - & * & - & ** \\
\hline Yr. $X$ cond. $X$ incr. & - & - & 一 & - & ** & - & ** & *** & - & - & ** & - \\
\hline Dates $X$ incr. (yr.) & $* *$ & $* * *$ & $* * *$ & $* * *$ & ** & - & $* * *$ & - & $* * *$ & $* * *$ & $* * *$ & $* * *$ \\
\hline $\begin{array}{l}\text { Cond. } \times \text { dates } \times \text { incr. } \\
(y r s)\end{array}$ & - & $*$ & - & - & - & $*$ & $* * *$ & - & - & 一 & - & - \\
\hline
\end{tabular}

Indicates significance at: ${ }^{*} .05, * * .01$ and $* * * .001$ level of probability.

biomass comparisons (Fig. 2 and 3), the density of plant feeders was significantly greater in the $0-10 \mathrm{~cm}$ increment in fair condition range (Fig. 4). Densities in the $10-30 \mathrm{~cm}$ increments were not different; however, numbers in excellent range were significantly greater in the 30-50 cm increments. When summed over all depth increments, the density of plant feeders ranged from 2 to 6 million $/ \mathrm{m}^{2}$ and was not significantly influenced by range condition (Tables 2 and 3 ).

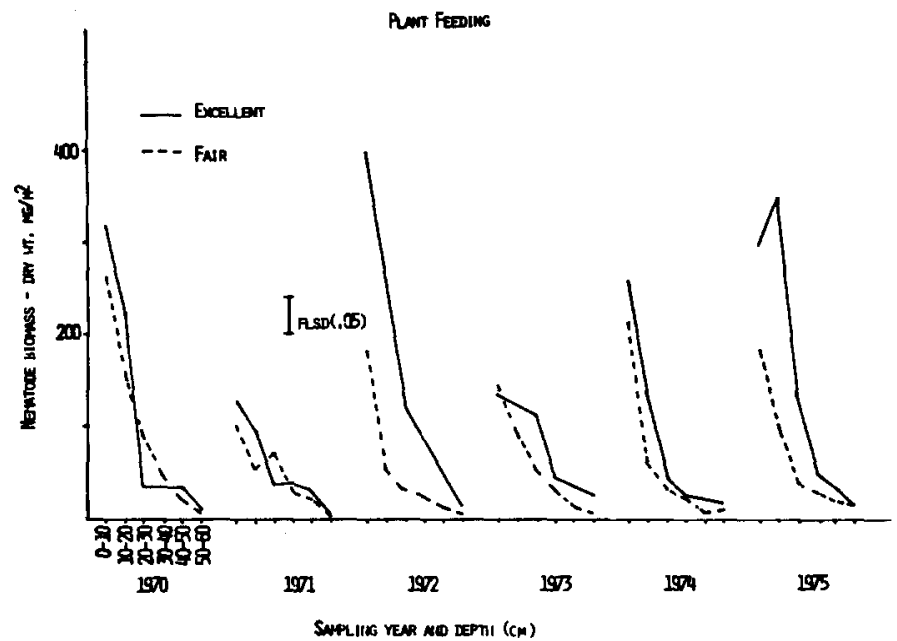

Fig. 3. Effect of range condition on biomass of plant feeding nematodes in July, 1970-1975.

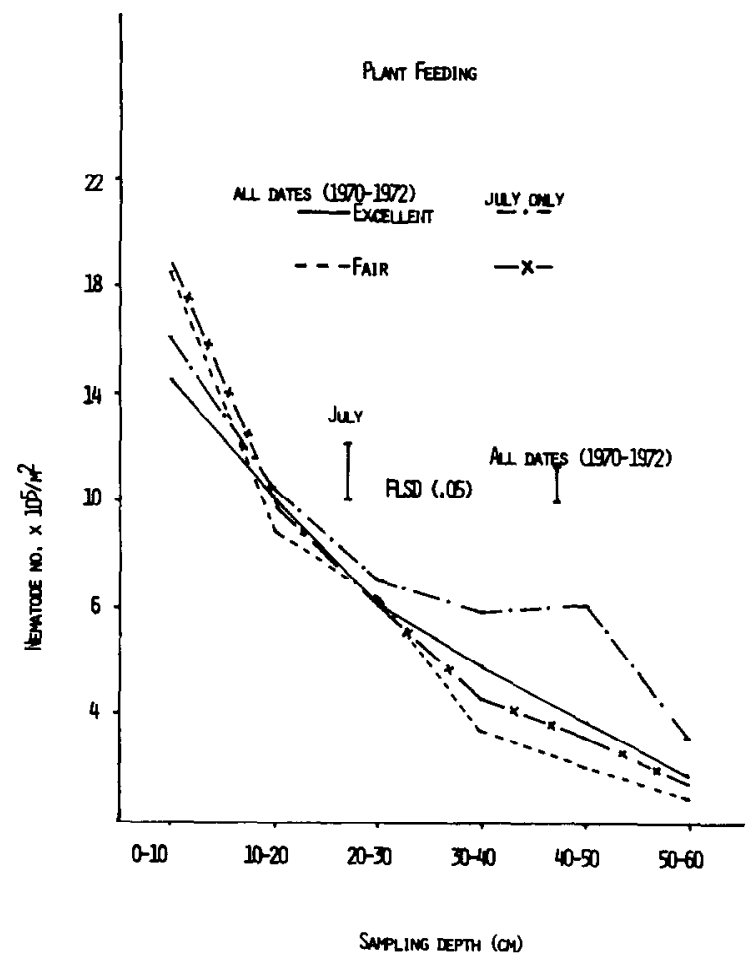

Fig. 4. Number of plant feeding nematodes in excellent and fair condition range at six sampling depths.

Table 3. Summary of significance in analyses of variance of nematode density and biomass data for July samples, $1970-1975$.

\begin{tabular}{|c|c|c|c|c|c|c|c|c|c|c|c|c|}
\hline Source: & $\begin{array}{c}\text { Plant } \\
\text { feeding }\end{array}$ & $\begin{array}{c}\text { Biomass } \\
\text { Plant } \\
\text { feeding }\end{array}$ & Stunt & Spiral & Pin & $\begin{array}{l}\text { Tylen- } \\
\text { chidae }\end{array}$ & Dagger & Lesion & $\begin{array}{l}\text { Dorylaims } \\
\text { (Plant } \\
\text { feeding- } \\
\text { excl. } \\
\text { dagger) }\end{array}$ & $\begin{array}{l}\text { Preda- } \\
\text { ceous }\end{array}$ & $\begin{array}{c}\text { Microbial } \\
\text { feeding }\end{array}$ & $\begin{array}{c}\text { Biomass, } \\
\text { Preda- } \\
\text { ceous }\end{array}$ \\
\hline & \multicolumn{12}{|c|}{ Probability of $F$} \\
\hline Condition & - & $*$ & - & - & - & - & $* *$ & 一 & - & - & - & - \\
\hline Year & - & $* * *$ & - & $* * *$ & - & - & $* * *$ & 一 & $* *$ & $*$ & $*$ & $*$ \\
\hline Yr. $X$ cond. & - & $* * *$ & - & $* *$ & - & - & $* * *$ & - & - & - & - & - \\
\hline Increments & $* * * 1$ & $* * *$ & $* * *$ & *** & $* *$ & $* * *$ & $\# * *$ & $* * *$ & $* * *$ & $* * *$ & $* * *$ & $* * *$ \\
\hline Cond. $X$ incr. & $*$ & $* * *$ & $* *$ & $* *$ & - & 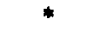 & $* * *$ & - & - & $* *$ & $* *$ & $\# *$ \\
\hline Yr. $\times$ incr. & $* *$ & $* * *$ & - & $* * *$ & $* *$ & - & $* * *$ & $*$ & $* * *$ & $* * *$ & $* * *$ & $* * *$ \\
\hline Yr. $X$ cond. $X$ incr. & - & $* * *$ & - & - & - & - & $* * *$ & - & $一$ & - & $*$ & - \\
\hline
\end{tabular}

Indicates significance at *.05, **.01 and ***.001 level of probubility. 


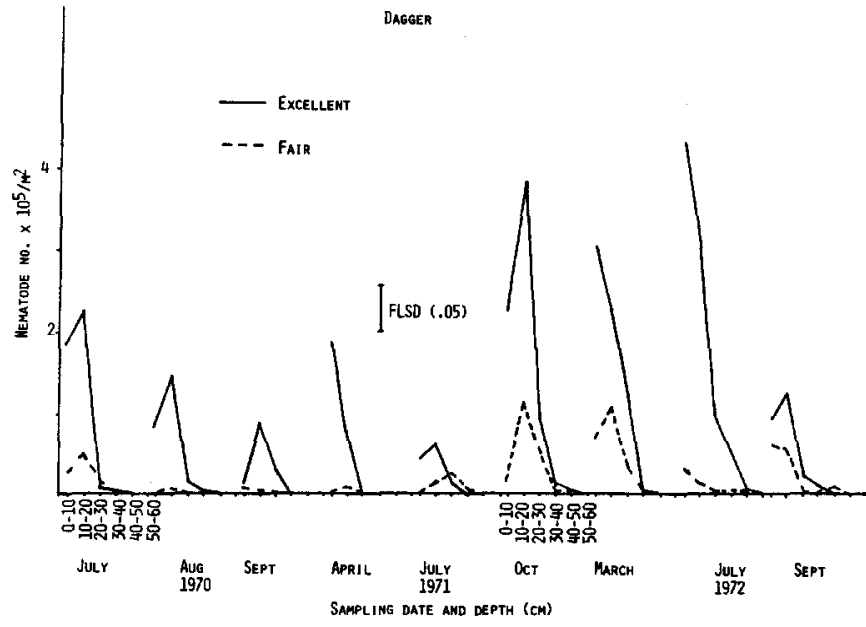

Fig. 5. Effect of range condition of number of dagger nematodes, 19701972.

As shown in Figures 2 and 3, the biomass of plant feeders in excellent range varied considerably with sampling date and year while biomass in fair range was comparatively uniform over years. In an attempt to explain this variation as well as the condition by increment interaction (Fig. 4) the densities of the taxonomic groupings comprising the plant feeding trophic level were examined.

Numbers of dagger nematodes were significantly greater in excellent condition range in the upper soil layers on most sampling dates and years (Fig. 5 and 6). However, numbers in both range types declined rapidly beyond the $30 \mathrm{~cm}$ sampling depth. Dagger nematodes are large nemas (Table 1) and they contribute substantially to biomass estimates for plant feeders. Consequently, the density fluctuations of dagger nematodes in excellent range (Fig. 5 and 6) correspond rather closely to the biomass fluctuations in excellent range (Fig. 2 and 3). The dominant dagger nematode was Xiphinema americanum (Table 1). This nematode is sensitive to environmental perturbations (Ponchillia 1972) and perhaps the more stable conditions in the near climax, excellent condition range favored their buildup. In fair condition range the shift in dominant vegetation as well as an increase in soil compaction through cattle trampling plus manuring effects apparently resulted in less favorable conditions. The preference of $X$. americanum for a more stable environment may also be related to difficulties encountered in rearing these nematodes in the greenhouse (Malek 1969). The dominance of dagger nematodes in excellent range is of further importance since several members of the group are virus vectors

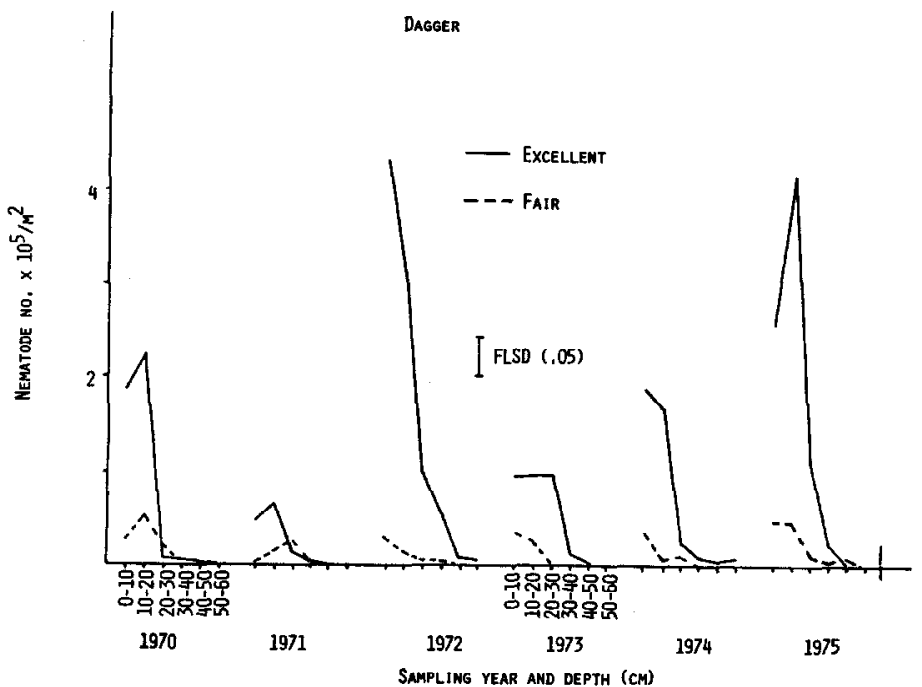

Fig. 6. Effect of range condition on number of dagger nematodes in July, 1970-1975.

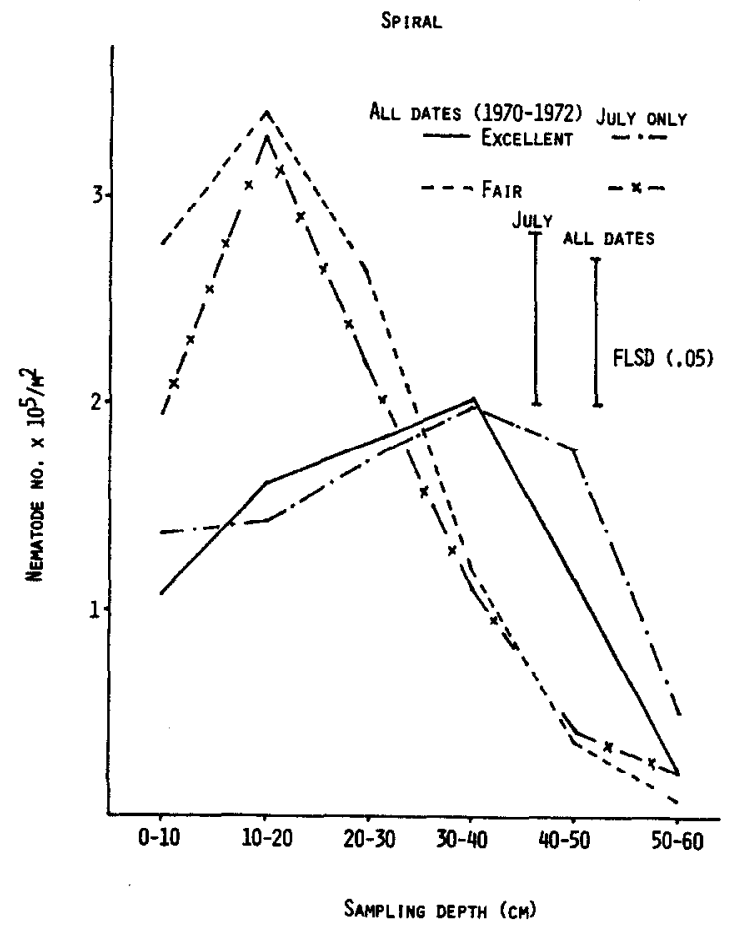

Fig. 7. Number of spiral nematodes in excellent and fair condition range at six sampling depths.

(including $X$. americanum) and thus their pathogenic potential is increased.

The vertical distribution of spiral nematodes varied with range condition (Fig. 7). Numbers were greater in the $0-30 \mathrm{~cm}$ increments in fair range and in the $30-50 \mathrm{~cm}$ increments in excellent range, which aids in explaining the interaction in Figure 4. Stunt nematodes were primarily limited to the $0-10 \mathrm{~cm}$ increment in both range conditions, and numbers were significantly greater in fair range (Fig. 8). The higher populations of stunt nemas in the 0-10

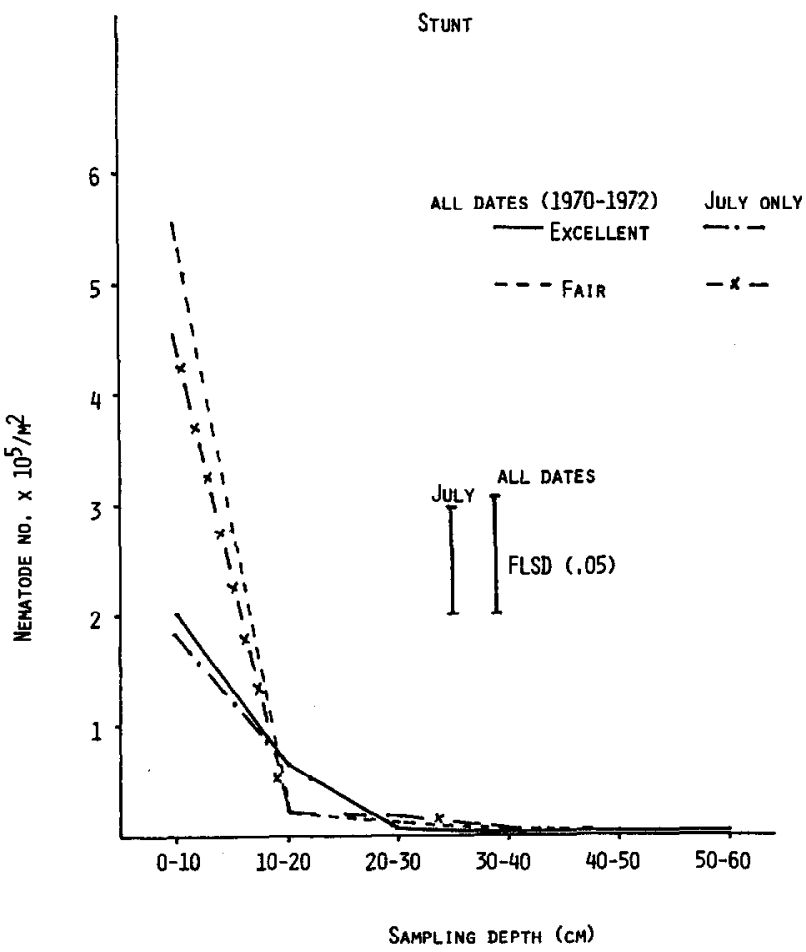

Fig. 8. Number of stunt nematodes in excellent and fair condition range ot six sampling depths. 
cm increment in fair range also contributed to the interaction in Figure 4. An interesting contrast in vertical distribution of spiral and stunt nematodes in fair range was noted in Figures 7 and 8 . The stunt nematodes were most abundant in the $0-10 \mathrm{~cm}$ increment while highest numbers of spiral occurred in the $10-20 \mathrm{~cm}$ increment. Competition for similar feeding sites or greater resistance in stunt nematodes to rapid desiccation or rapid changes in soil temperature may account for this segregation. Soil temperature alone does not seem to be responsible since the dominant species in both taxonomic groupings had a similar optimal constant temperature for reproduction of $25^{\circ} \mathrm{C}$ (author's unpublished).

The pin nematodes, Tylenchidae, plant feeding dorylaims (excluding dagger), and lesion nematodes are compa ratively small nematodes (Table 1) or occurred in comparatively low populations, and thus quantitative data is not presented in the text; copies of the data are available upon request of the authors. Numbers of pin nematodes were significantly greater in the $0-30 \mathrm{~cm}$ increments in excellent range in 1970 and in the $20-30 \mathrm{~cm}$ increment in 1972 . Pin are tiny nematodes (Table 1) and while their densities were comparatively high, particularly in the upper soil layers, their contribution to the plant feeding biomass was small. The Tylenchidae did not exhibit any consistent preference for conditions in either range type. It is possible that the comparatively large number of species contained in this taxonomic grouping (Table 1) interacted in such a manner as to mask treatment effects. The plant feeding dorylaims (excluding dagger) were more numerous in excellent condition range in the $10-30 \mathrm{~cm}$ increments. The number of lesion nematodes was significantly higher in fair range in the 0-20 cm increments. However, their overall populations were an order of magnitude less than other plant feeders and thus they appear to be of lesser importance at the Cottonwood site than other taxa. In New Zealand pastures lesion nematodes also increased in response to increased grazing pressure and were therefore believed to be partially responsible for decreased forage yields (Yeates 1977).

Effects of range condition on other trophic levels were also investigated. Populations of microbial feeders were significantly greater in fair range only in 1972 in the $0-10 \mathrm{~cm}$ increment (Fig. 9). When July only samplings were compared (Fig. 10) numbers of microbial feeders were greater only in 1972 and 1974 in the $0-10 \mathrm{~cm}$ increment in fair range. It thus appears that range condition has less effect on this diverse (Table 1) taxonomic grouping. Maximum numbers of microbial feeders occurred in the $0-10 \mathrm{~cm}$ increment (Figs. 9 and 10) in both range types. This is the layer of greatest mulch accumulation which would result in an increase in food sources for this group and is in agreement with results of other

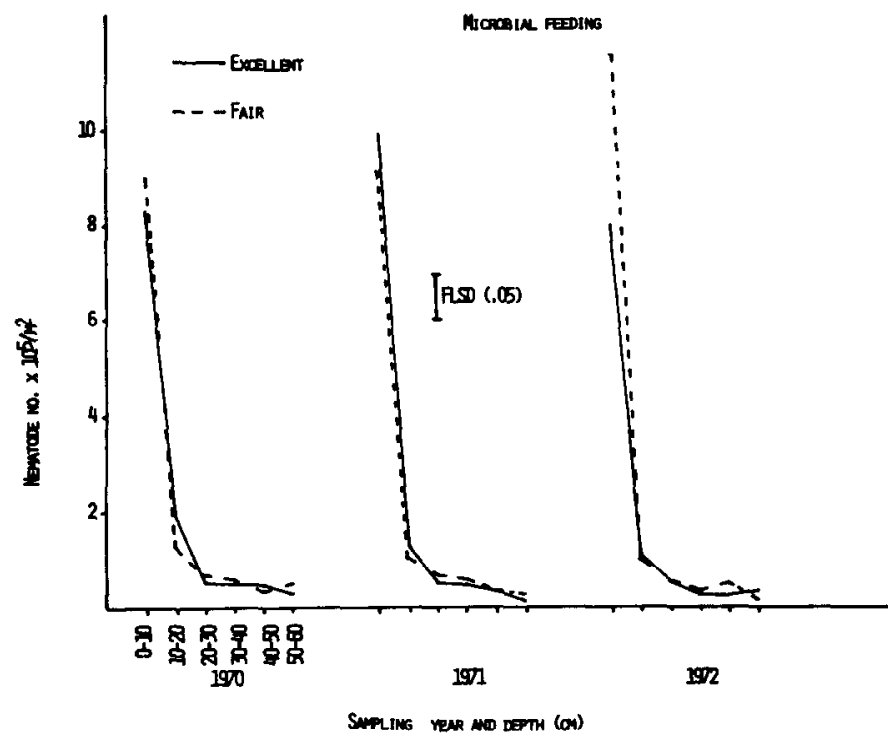

Fig. 9. Effect of range condition on number of microbial feeding nematodes at six sampling depths. 1970-1972.

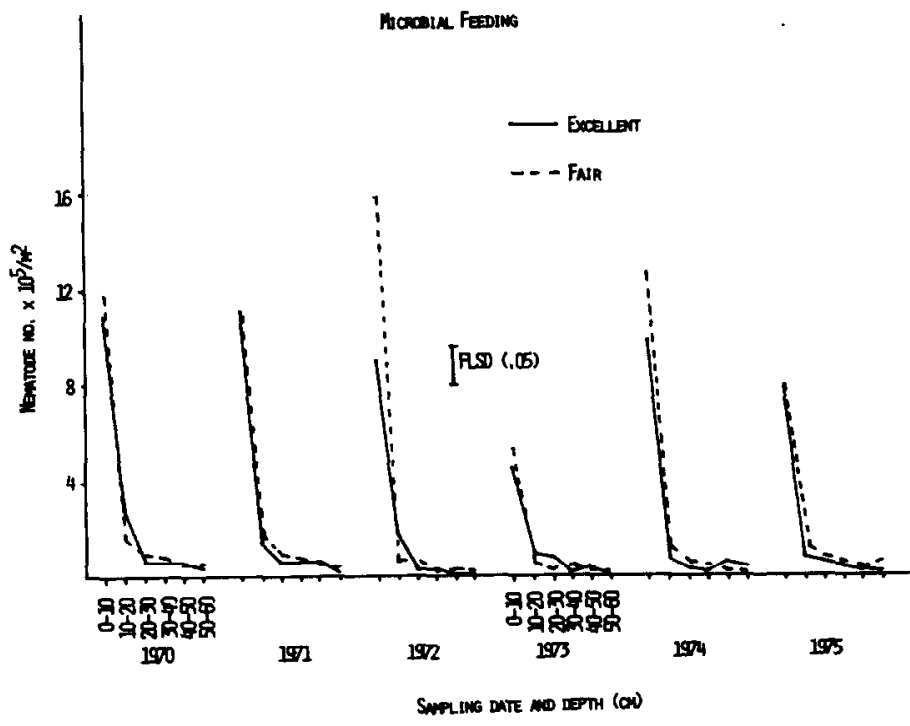

Fig. 10 Effect of range condition on number of microbial feeding nematodes in July, 1970-1975.

studies (Wasilewska 1974). Density of predaceous forms was higher in excellent range in the $0-30 \mathrm{~cm}$ increments (Fig. 11). On the basis of numbers, it might appear that microbial feeders could provide a sufficient food source for predators (Fig. 9, 10 and 11). In addition, some predators do feed upon microbial feeders (Thorne 1939, Goodey 1951, Tjepkema et al. 1971). However, the average biomass of microbial feeders over both range conditions ranged from 59 to $127 \mathrm{mg} / \mathrm{m}^{2}$ to $60-\mathrm{cm}$ depth while that of predators ranged from 281 to $797 \mathrm{mg} / \mathrm{m}^{2}$. It would thus appear that microbial feeders are not the sole food source for predators. Many of the predators was similar to that of plant feeders, which ranged from 262 to $686 \mathrm{mg} / \mathrm{m}^{2}$ over both range conditions. This may suggest that plant feeders are also utilized as a food source, thus it is possible that predators may aid in the biological control of plant feeding populations. Further support for this possibility is the comparatively slow decline in numbers of predators with increasing sampling depth (Fig. 11) when compared to microbial feeders

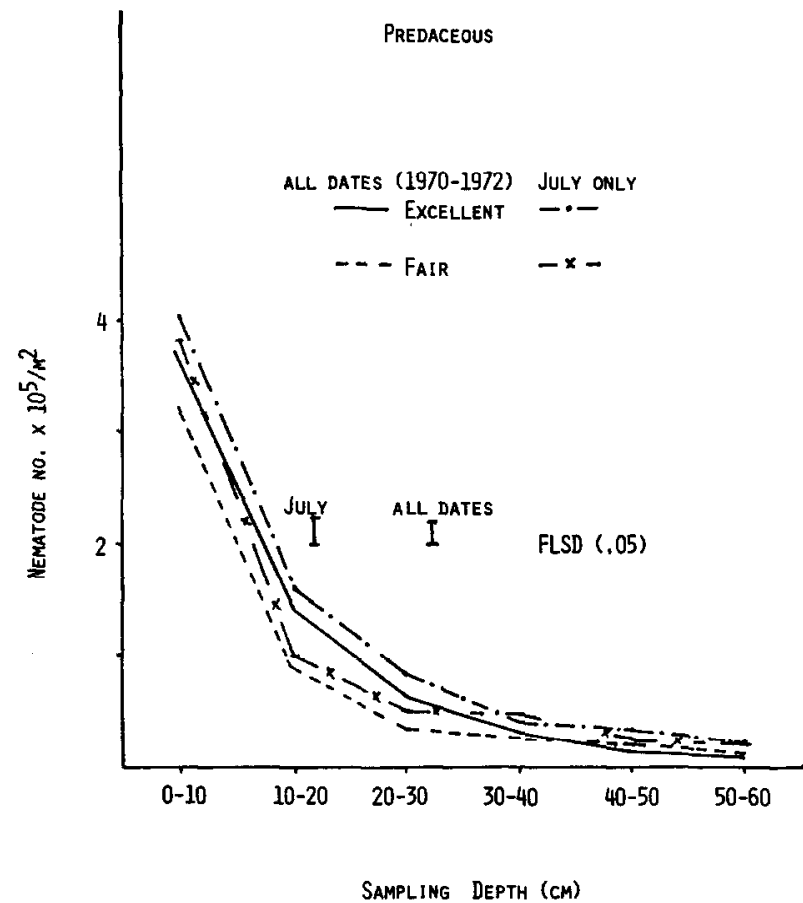

Fig. 11. Number of predaceous nematodes in excellent and fair condition range at six sampling depths. 
(Figs. 9 and 10). It is also possible that certain of the forms included among the predaceous (Table 1) are omnivorous (Thorne 1939, Hollis 1957, and Wasilewska 1974) and also feed upon plant material. However, predaceous nematodes do not feed only on other nematodes; mites, mite eggs, enchytraeids, enchytraeid eggs, and protozoa are also known sources of food.

The dominant herbivore group in terms of biomass at the Cottonwood site was cattle (Table 4), followed by plant feeding nematodes, plant feeding arthropods, and birds. Biomass estimates for small mammals were not obtained directly from the treatment areas; however, estimates from a nearby area were approximately $.004 \mathrm{~g} / \mathrm{m}^{2}$ (Lewis 1971). Although cattle biomass is much higher than that for nematodes, it is probable that nutrient intake per unit

Table 4. Biomass estimates for various consumer organisms at the Cottonwood site in excellent and fair range condition.

\begin{tabular}{lcc}
\hline & \multicolumn{2}{c}{ Biomass $\mathrm{g} / \mathrm{m}^{2}$ (dry wt.) $^{\mathbf{1}}$} \\
\cline { 2 - 3 } & Excellent & Fair \\
\hline Cattle $^{2}$ & 2.85 & 1.69 \\
Plant feeding nematodes & 0.54 & 0.38 \\
Plant feeding arthropods & .095 & .085 \\
Birds & .002 & .007
\end{tabular}

'All values are time-weighted means. Cattie and bird data obtained from Lewis 1971, arthropod data from McDaniel 1971.

${ }^{2}$ Hypothetical cattle populations-based on 12 and 20 acres/animal unit/year for excellent and fair range condition.

biomass is much higher for nematodes since as Kevan (1962) emphasizes small organisms respire at a much higher rate than large organisms. In addition, Scott et al. (1979) have estimated that nematodes may consume three times as much range vegetation as cattle in a mixed prairie ecosystem. The high nutrient intake also aids in explaining the significant plant growth response following nematicide treatment (Smolik 1977).

The effect of range condition on density and biomass of plant feeding, predaceous and microbial feeding nematodes at various US/IBP Grassland Biome sites is shown in Table 5. With the possible exception of Osage the only perennial grassland site at which range condition appeared to influence biomass of plant feeding nematodes was at Cottonwood. This was also the only site in mixed prairie and heavy grazing resulted in a significant shift in dominant vegetation. This shift as well as edaphic effects of cattle grazing apparently combined to result in a lowering of plant feed- ing nematode biomass. Further studies designed to measure the effects of a greater range of grazing pressures in the hope of locating a grazing regimen that would result in a lowering of plant feeding nematode biomass without a drastic change in floral composition would be desirable.

Overall it is concluded that nematodes constitute a significant proportion of the faunistic biomass in a mixed prairie ecosystem. Furthermore they deserve increased emphasis in future grassland studies.

\section{Literature Cited}

Andrassy, 1. 1956. The determination of volume and weight of nematodes. Acta Zool. Acad. Sci. Hung. 2(1-3): 1-15.

Beetle, A.A. 1970. Recommended plant names. Wyoming Agr. Exp. Sta. Res. J. 31, 124 p.

Carmer, S.G., and M.R. Swanson. 1971. Detection of differences between means. A Monte Carlo study of five pairwise multiple comparison procedures. Agron. J. 63:940-945.

Christie, J.R., and V.G. Perry. 1951. Removing nematodes from soil. Proc. Helminthol. Soc. Wash. 18:106-108.

Ferris, V.R. 1967. Life history studies of certain dorylaimoid nematodes of the Waubash River Basin. Nematologica 13:142-143.

Ferris, J.M. 1972. Terrestrial decomposition processes: Population and energy dynamics of selected invertebrates. Eastern Deciduous Forest Biome Memo. Rep. No. 72-166. 12 p.

Freckman, D.W., D.A. Duncan, and J.R. Larson. 1979. Nematode density and biomass in an annual grassland ecosystem. J. Range Manage. $32: 418-422$.

Goodey, T. 1951. Soil and Freshwater Nematodes. John Wiley and Sons, Inc. New York, N.Y.

Hitchcock, A.S., and A. Chase. 1951. Manual of the grasses of the United States, 2nd Ed. U.S. Dep. Agr. Misc. Publ. 200, 1051 p.

Hollis, J.P. 1957. Cultural studies with Dorylaimus ettersbergensis. Phytopathology 47:468-473.

Kevan, D.R. McE. 1962. Soil Animals. Philosophical Library Inc., New York, N.Y. p. 126-158.

Lewis, J.K. 1970. Comprehensive network site description. Cottonwood U.S. I.B.P. Grassland Biome Tech. Rep. No. 39, Colorado State Univ., Ft. Collins. $26 \mathrm{p}$.

Lewis, J.K. 1971. The grassland biome. A synthesis of structure and function, 1970. p. 317-387. In: Preliminary Analysis of Structure and Function in Grasslands. N.R. French, ed. Range Science Dept. Sci. Ser. No. 10. Colorado State Univ., Ft. Collins.

Malck, R.B. 1969. Population fluctuations and observations of the life cycle of Xiphinema americamum associated with Cottonwood (Populus deltoides) in South Dakota. Proc. Helminthol. Soc. Wash. 36:270-274.

McDaniel, B. 1971. The role of invertebrates in the grassland biome, p. 267-315. In: Preliminary Analysis of Structure and Function in Grasslands. N.R. French, ed. Range Sci. Dep. Sci. Ser. No. 10. Colorado State Univ., Ft. Collins.

Table 5. Density and biomass of plant feeding, predaceous and microbial feeding nematodes from several US/IBP Grassland Biome sites.

\begin{tabular}{|c|c|c|c|c|c|c|c|c|c|}
\hline \multirow[b]{2}{*}{ Location } & \multirow{2}{*}{$\begin{array}{l}\text { Sampling } \\
\text { depth }(\mathrm{cm})\end{array}$} & \multirow{2}{*}{$\begin{array}{l}\text { Range } \\
\text { condition }\end{array}$} & \multicolumn{2}{|c|}{ Plant feeding } & \multicolumn{2}{|c|}{ Predaceous } & \multicolumn{2}{|c|}{ Microbial feeding } & \multirow[b]{2}{*}{ Source } \\
\hline & & & Density' & Biomass $^{2}$ & Density & Biomass & Density & Biomass & \\
\hline Ale, & 40 & Excellent & $948-2762$ & $.06-.16$ & $111-485$ & $.04-.15$ & $261-2074$ & $.02-.19$ & (Smolik et al. \\
\hline Washington & & Good + & $1793-3063$ & $.08-.16$ & $114-419$ & $.04-.13$ & $713-1574$ & $.06-.14$ & 1976) \\
\hline Bridger, & 50 & Mountain (NG) & $3091-3712$ & $.32-.36$ & $479-540$ & $.25-.30$ & $2467-2992$ & $.27-.39$ & (4) \\
\hline Montana & & Grassland (G) & $2486-2681$ & $.29-.30$ & $439-538$ & $.23-.31$ & $1756-3273$ & $.19-.43$ & \\
\hline Cottonwood, & 60 & Excellent & $2457-5595$ & $.32-1.00$ & $364-969$ & $.34-.89$ & $725-1599$ & $.06-.13$ & Present \\
\hline South Dakota & & Fair & $2497-5098$ & $.22-.68$ & $234-803$ & $.22-.73$ & $757-1684$ & $.06-.13$ & Study \\
\hline Jornada, & 30 & Excellent & 2995 & .02 & 69 & .01 & 642 & .04 & (4) \\
\hline New Mexico & & Fair + & 323 & .01 & 53 & .01 & 523 & .03 & \\
\hline Osage, & 60 & Excellent & $1830-4398$ & $.19-.38$ & $723-512$ & $.12-.17$ & $835-1391$ & $.06-.10$ & (4) \\
\hline Oklahoma & & Fair + & $2380-2867$ & $.16-.19$ & $262-567$ & $.06-.13$ & $1387-2190$ & $.10-.16$ & \\
\hline Pawnee, & 60 & Excellent & $1767-2337$ & $.16-.19$ & $221-433$ & $.07-.11$ & $2068-3121$ & $.15-.21$ & (4) \\
\hline Colorado & & Good & $2285-3479$ & $.12-.19$ & $95-667$ & $.03-.17$ & $2348-2744$ & $.16-.20$ & \\
\hline San Joaquin, & 60 & Annual (NG) & $533-4393$ & $.07-.58$ & $915-927$ & $.41-.50$ & $5900-7164$ & $.33-.35$ & (4) \\
\hline California & & Grassland (G) & $675-1383$ & $.08-.18$ & $432-602$ & $.20-.41$ & $3057-7401$ & $.18-.34$ & \\
\hline
\end{tabular}

Thousands of nematodes per $\mathrm{m}^{2}$, each value average of six reps. per sampling date.

2Dry weight in $\mathrm{g} / \mathrm{m}^{2}$ to indicated depth.

${ }^{3}$ Grazed or not grazed by cattle.

Authors (unpublished results).

sOne sampling date only. 
Nielsen, C.0. 1967. Nematoda. p. 198-211. In: Soil Biology A. Burgess and F. Raw. ed. Acad. Press. New York, N.Y.

Norton, D.C., and D.P. Schmitt. 1978. Community analysis of plant parasitic nematodes in the Kalsow Prairie, lowa. J. Nematol. 10: 171176.

Orr, C.C., and O.J. Dickerson. 1967. Nematodes in true prairie soils of Kansas. Trans. Kansas Acad. Sci. 69:317-334.

Ponchillia, P.E. 1972. Xiphinema americanum as affected by soil organic matter and porosity. J. Nematol. 4:189-193.

Schmitt, D.P., and D.C. Norton. 1972. Relationships of plant parasitic nematodes to sites in native Iowa prairies. J. Nematol. 4:200-206.

Scott, J.A., N.R. French, and J.W. Lettham. 1979. Patterns of consumption in grasslands. p. 89-105. In: Perspectives in Grassland Ecology. N.R. French, ed. Springer-Verlag, New York, N.Y.

Smolik, J.D., and L.E. Rogers. 1976 Effects of cattle grazing and wildfire on soil-dwelling nematodes of the shrub steppe ecosystem. J. Range Manage. 29:304-306.

Smolik, J.D. 1977. Effect of nematicide treatment on growth of range grasses in field and glasshouse studies. p. 257-260. In: Proceedings of Below-ground Ecosystem Sympsoium. J.K. Marshall, ed. Colo. State Univ. Range Science Series No. 26.

Soil Conservation Service. 1969. Technical guide for South Dakota. Soil Conserv. Serv., Huron, South Dakota.

Thorne, G., and H.H. Swanger. 1936. A monograph of the nematode genera Dorylaimus, Dujardin, Aporcelaimus N.G., Dorylaimoides N.G. and Pungentus N.G. Capita Zool. 6:1-223.
Thorne, G. 1939. A monograph of the nematodes of the superfamily Dorylaimoidea. Capita Zool. 8:1-261.

Thorne, G. 1961. Principles of Nematology. McGraw-Hill Book Co. Inc., New York, N.Y.

Thorne, G., and R.B. Malek. 1968. Nematodes of the Northern Great Plains. Part I. Tylenchida (Nemata:Secernentea). Tech. Bull. 31 Agr. Exp. Sta. South Dakota. State Univ., Brookings.

Thorne, G. 1974. Nematodes of the Northern Great Plains. Part II. Dorylaimoidea in part (Nemata:Adenophorea). Tech. Bull. 41. Agr. Exp. Sta. South Dakota State Univ., Brookings.

Tjepkema, J.P., V.R. Ferris, and J.M. Ferris. 1971. Review of the genus Aporcelaimellus Heyns, 1965 and six species of the genus Eudorylaimus Andrassy, 1959. (Nematoda:Dorylaimida) Res. Bull. 882. Agr. Exp. Sta. Purdue Univ., Lafayette, Ind.

Wallace, H.R. 1963. The. Biology of Plant Parasitic Nematodes. Edward Arnold LTD. London. p. 62-69.

Wasilewska, L. 1974. Quantitative evaluation of the occurrence of nematodes in meadow soil from the surroundings of Sofia (Bulgaria) Zesz. probl. Post. Nauk. roln., 154:213-225.

Yeates, G.W. 1974. Studies on a climosequence of soils in tussock grasslands. No. 2 Nematodes. N.Z.J. Zool. 1:171-177.

Yeates, G.W. 1977. Soil nematodes of New Zealand pastures. Soil Science. 123:415-422.

Yuen, P.H. 1966. The nematode fauna of the regenerated woodland and grassland of broadbalk wilderness. Nematologica 12:195-214.

\section{Membership in the Society for Range Management. . .}

is open to those engaged in or interested in the study. management, or use of range ecosystems and the intelligent use of all range resources

includes research scientists, ranchers, governmental agency administrators and technical personnel, teachers, students, and people from the business community

provides members with two publications - one oriented to research (Journal of Range Management) and the other oriented to proctical resource manogement (Rangelands) offers opportunities for face-to-face exchange of ideas at local, notional, and intemational meetings of the Society.

Dues vary according to type of membership and geographical section. For application forms and additional information, contact the:

Execulive Secretary

Society for Range Mancoement

2760 West Fifth Avenue

Denver. Colorado 80204

(303) 571-0174 